NIHON REOROJĪ GAKKAISHI Vol.26, No.3, 181 185 (1998)

(C)1998 The Society of Rheology, Japan

論文

\title{
A Study on the Flow of Molten Polymers in a Mold
}

\section{- An Investigation on Mold Printability -}

Yoshiaki $\mathrm{KaNOH}^{* 1}$, Takafumi Nisfmura ${ }^{* 1}$, Sadamoto IToH ${ }^{* 1}$, Hiromoto Usu ${ }^{* 2}$, and Takashi SAEK ${ }^{* 3}$

*1 Corporate Research \& Development Division, Ube Industries, Ltd, 1980 Okinoyama Kogushi, Ube-city, 755, Japan

*2 Department of Chernical Science and Engineering, Kobe University, 1-1 Rokkodai, Nada, Kobe-city, 657, Japan

*3 Department of Applied Chemistry and Chemical Engineering, Yamaguchi University, 2557 Tokiwadai, Ube-city, 755, Japan

Filling up flows of several molten polymers in a rectangular cavity grooved on a mold surface were experimentally investigated by means of a flow visualization technique. The conditions for the higher mold printability were obtained as a function of polymer melt temperature, mold wall temperature, air blow pressure and air blow velocity.

Key Words : Printability/Molten polymer/Contact surface/Visual test

\section{高分子溶融体の金型内微小流動 \\ - 金型転写性の研究 -}

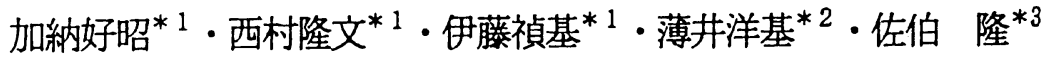 \\ （原稿受理：1997年12月10日）
}

\section{1.腥言}

高分子溶融体の金属表面の流れのひとつの現象でる金型転写時の 金型内微小流動については、成形品の良し悪しに重大な影篦を及ほす にもかかからず、ほとんど研究がされておらず、その現象について は未解明なところか多い。したがって、従来より、例えばブロー成形 における金型転写性向上については、経験的にブロー死力を上けたり 金型温度を高く設定するということから般に行われているがこれは 保圧と型温を上げるという射出成形での金型転写性向上の処方と基 本的に同一であり樹脂か詅やされて固化するまでの間に転写させ る」という現場での法則に則っている。また、数少ない研究の中で、 佐野らは、エンジニアリングプラスチックのブロー成形品の表面状 㓦の品質向上に関して、過去の経験に基ついて特性要因を調へパリ

" 宇部興産枅究開発本部 ₹755 山口県宇部市大字小串字神の山1980

2 神戸大学工学部応用化学科 $=657$ 兵庫県神戸市触区六甲台町 $1-1$

* 山口大学工学部広用化学工学科 $\bar{T} 755$ 山口県宇部市常然台2557
ソンの状琶 成形条件 金型の状態の三つの大きな要素に分類し、各 因子の寄与の程度を知るために、各条件を变えてサンプル成形を行い その成形品の表面状態について評価している。その結果、成形時の金 型キャビティ温度はより高いほうが 成形品の表面状態の品質向上に より寄与しているとしている。また、Furuyaら ${ }^{2333}$ は、さらに一步踏 み込んて、ブロー成形において金型転写か㴗、原因とその原因解明結 果に基つれた方策について検討を行っている。すなわち、ブロー成形 では、アトラップしやすいというプロセス上の差異か転写性に決定 的な影㽧を及ほしていると考え、榯脂流動と脱気タイミングを制御す る金型加熱冷却プロセス（ヒートノクールプロセス）を考察し、ブロ 一成形でも射出成形と同等の転写性を実現できるとしている。しかし ながら、これらの研究では、理論的な把握 つまり溶融榯指の金型内 で微小流動についての正確な把握、転写メカニズムの把层かできて おらず、それに基ついた条件の道正化相れていなかった。 そこで本研究では、ブロー成形 圧空成形におけろ金型転写のモテ ルとして、小さい矩形瑇部を有する金型を用いて可視化実験を行い、 
溶蝴指の金型内微小流動を観察した。尚、本研究ては、可視化実験 により、溶融樹指の金型内微小流動を時々刻々と観察するために、金 型転写のモテルすなわち矩形溝部の仕样（断面形状、大きさ、アスペ クト比等) を綿密に検討した。また、実験に用いる樹脂之固体界面 (金 型) の温度制御や金型転写の評価の方法については本研究において工 夫した。次に、この結果から、金型温度、樹指温度、吹き込みエア压 力、吹き込み工ア速度等の因子が金型転写性に及ぼす影響を明らかに し、その原因について考察を行うとともに、金型高転写の条件を求め た。

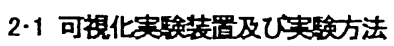

\section{2. 実験}

Fig. 1，Fig. 2 に可視化実験装置の概要と観察点の拡大図を示す。 金型の転写面には、矩形断面の瑇を設け、瑇の端面に観察用空を設

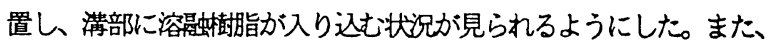
金型の满部の近くには、鏡面状の光沢部を設け、実験後に成形品表面 の光沢度を測定することにより、光沢面における金型転写性力呯価て きるようにした。実験は、事前に丁ダイ付きの押出機て樹指シートを 成形し、実験時にホットプレスで加熱後、溶融した楜指シートを当該 の金型にセットして行った。 金型を型綐め後、エアを吹き込み、ブロ 一アップして㯘脂シートを金型転写面に接触させた。矩形断面の幥部 に入り込む樹指シートは下方（金型溝部の底面の投光用ガラス空）か

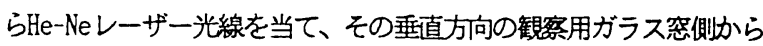
CDDメラて撮影した。本夷験は、樹脂種類及び金型温度、樹指温度、 吹き込みエア圧力、吹き込子エア流速等の諸条件を変えて行った。

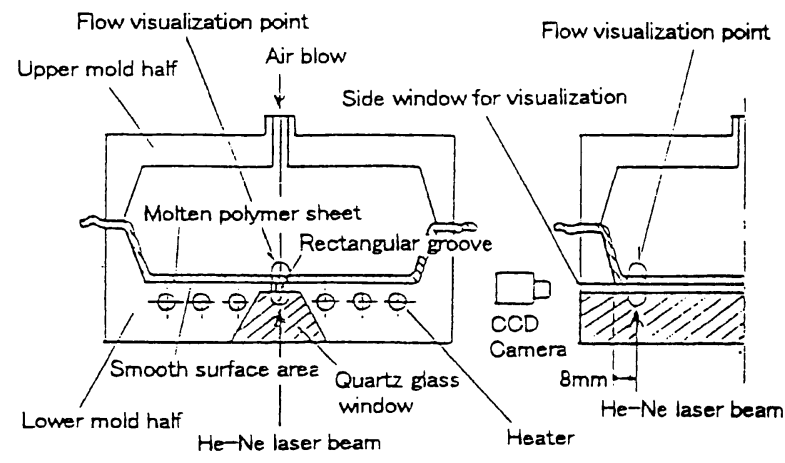

Fig. 1 Schematic drawing of visualization system

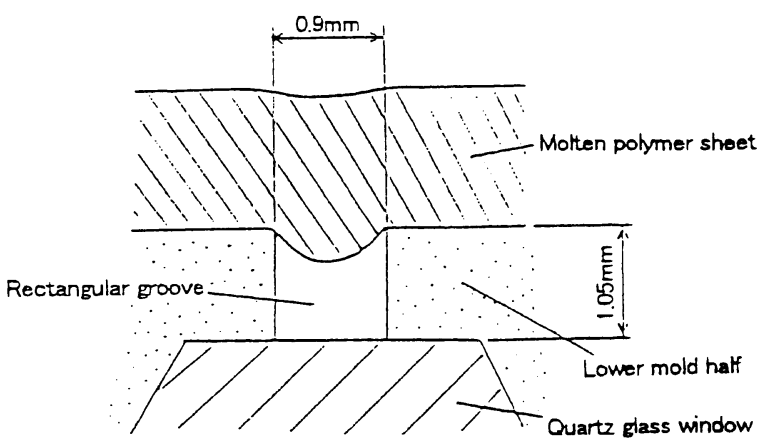

Fig. 2 Closed-up drawing of the flow visualization

\section{2 实鉒件}

金型の材質は炭素鋼て、金型の評価面における矩形满部の断面寸法 （幅×深さ）は0. $9 \mathrm{~mm} \times 1.05 \mathrm{~mm}$ 、光沢部の表面粗さ（最大高さ）は Rmax $0.4 \mu \mathrm{m}$ でる。

樹脂シートについては、厚さが2. $2 \mathrm{~mm} て 、$ 楜脂種類は次に示す 3 種 類である。

(1)高密度ポリエチレン(HDPE) チッソ製 B812

(2)ポリプロピレン(PP) 宇部興産製 ZS633

(3)ポリプロピレン(PP) 宇部興産製 $\mathrm{B} 301 \mathrm{H}$

また、各榯脂における設定条件を Table I〜mに示す。

Table I Experimental Conditions for HDPE(B812) test runs

\begin{tabular}{|l|r|r|r|r|r|r|r|r|r|r|r|r|}
\hline Parremeter Pan number & 1 & 2 & 3 & 4 & 5 & 6 & 7 & 8 & 9 & 10 & 11 & 12 \\
\hline Pohmer melt temperature (c)) & 200 & 220 & 180 & 200 & 200 & 200 & 200 & 200 & 200 & 200 & 200 & 200 \\
\hline Air blow pressure (kef/cm) & 5 & 5 & 5 & 7.5 & 2.5 & 5 & 5 & 5 & 5 & 5 & 5 & 5 \\
\hline $\begin{array}{l}\text { Air blow volocity } \\
\text { (Blowup time) (soc) }\end{array}$ & 3 & 3 & 3 & 3 & 3 & 1 & 9 & 3 & 3 & 3 & 3 & 3 \\
\hline Mold wall tomperature (C) & 60 & 60 & 60 & 60 & 60 & 60 & 60 & 80 & 90 & 100 & 105 & 110 \\
\hline
\end{tabular}

Table II Experimental Conditions for $\mathrm{PP}(\mathrm{ZS633})$ test runs

\begin{tabular}{|l|r|r|r|r|r|r|r|r|r|r|r|r|}
\hline Parameter Ram number & 1 & 2 & 3 & 4 & 5 & 6 & 7 & 8 & 9 & 10 & 11 & 12 \\
\hline Polymer melt temperature (C) & 215 & 235 & 195 & 215 & 215 & 215 & 215 & 215 & 215 & 215 & 215 & 215 \\
\hline Air blow pressure (kgf//m²) & 5 & 5 & 5 & 7.5 & 2.5 & 5 & 5 & 5 & 5 & 5 & 5 & 5 \\
\hline $\begin{array}{l}\text { Air blow velocity } \\
\text { (Blow-up time) (sec) }\end{array}$ & 3 & 3 & 3 & 3 & 3 & 1 & 9 & 3 & 3 & 3 & 3 & 3 \\
\hline Mold wall temperature (C) & 60 & 60 & 60 & 60 & 60 & 60 & 60 & 80 & 90 & 100 & 105 & 110 \\
\hline
\end{tabular}

Table III Experimental Conditions for PP(B301H) test runs

\begin{tabular}{|l|r|r|r|r|r|r|r|r|r|r|r|r|}
\hline Parameter Run number & 1 & 2 & 3 & 4 & 5 & 6 & 7 & 8 & 9 & 10 & 11 & 12 \\
\hline Polymer mett temperature (C) & 215 & 235 & 195 & 215 & 215 & 215 & 215 & 215 & 215 & 215 & 215 & 215 \\
\hline Air blow pressure (kef/cm? & 5 & 5 & 5 & 7.5 & 2.5 & 5 & 5 & 5 & 5 & 5 & 5 & 5 \\
\hline $\begin{array}{l}\text { Air blow velocity } \\
\text { (Blow up time) (soc) }\end{array}$ & 3 & 3 & 3 & 3 & 3 & 1 & 9 & 3 & 3 & 3 & 3 & 3 \\
\hline Mold wall temperature (C) & 60 & 60 & 60 & 60 & 60 & 60 & 60 & 80 & 90 & 100 & 105 & 110 \\
\hline
\end{tabular}

\section{3 画像処理方法}

画像取り込みボードを使ってパソコンのモニターに金型の满部内 て微小流動中の樹脂シートの各時間における静止画像を再生し、樹指 シートの下面の位置を計測した。サンプリングは矩形断面满の幅全域 にわたって約20点について行いサンプリングしたテー夕はパソコン に読み込まれ 二次元 $(x, y)$ 座摽として出力される。

\section{3. 实硢䊅果及ひ考察}

\section{$3 \cdot 1$ 画像边理吉果}

画像処理した例をFig. 3 に示す。尚、時間tはブローアップ開始よ りの時間を示す。

\section{2 矩形清部での入り込み速度、最終到迋值及ひ最終空面積の算定}

裂幅方向中央部で墈脂シート下面位置の時間的变化から入り込 み速度a，最終到達值 向axを求めた。 

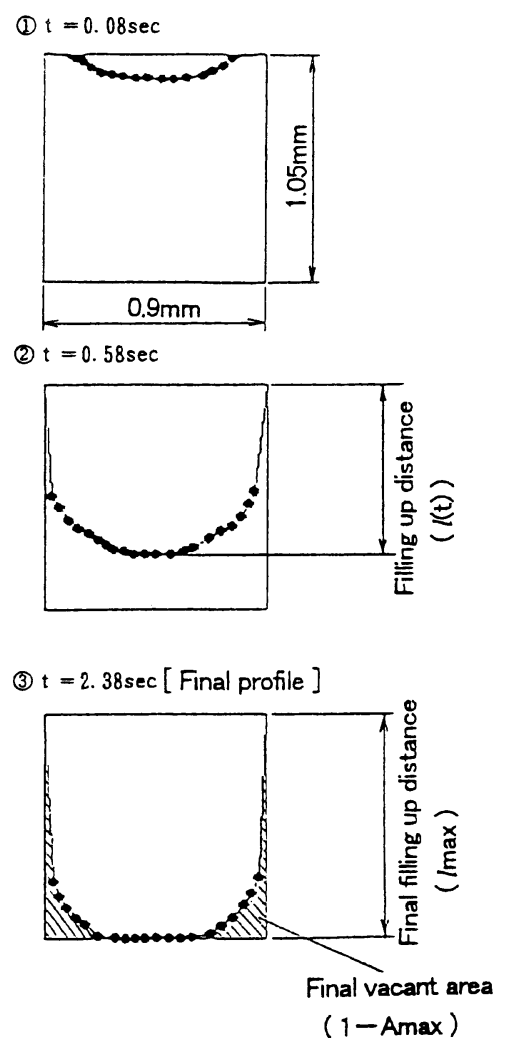

Fig. 3 Filling up characteristics of a molten polymer in a rectangular cavity grooved on the mold surface

最終到達值については、Fig. 33のように、入り込だ楜脂シート か変位しなくなったときの樹指シート下面の位㯰とした。尚、最終到 達値は必ずしも金型の矩形溝部の下面（底面）に達せず、途中て止ま ることもある。更に、Fig. 33のように、潵部断面の全面樍心に対し て、最終到達時における溍部断面のシートの充填面積 S maxを求め これより無次元の未充填面積 $\left[\left(S_{0}-S_{\max }\right) / S_{0}=1-\Lambda \max \right]$ を算定し 最終空面棈とした。

また、画像データの上からエア吹き込み開始時期を特定すること かできなかったので、エア吹き込みによりブローアップが開始する夕 イミングか起点となるように補正を行った。即ち、画像処理より得ら

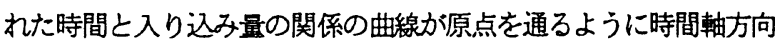
にシフトした。

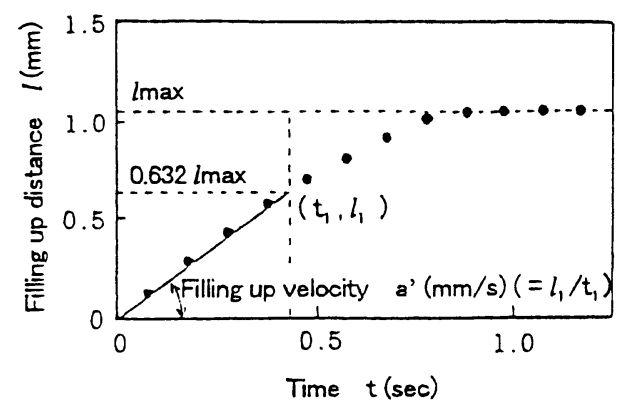

Fig. 4 Definition of filling up velocity (HDPE, Run 6)
次に、Fig. 4 に示すように、この曲線の傾きから入り込み速度を 求めた。この曲線の原点における傾きから求める方法もあるが 精度 が良くないのて、、今回は、入り込み速度は、ステップ底答におけるー 次革れモテルから求めた。即ち、一次遅れモテルの時定数はステップ 応答の值が最終値の63.2\%になる時間であるため，曲線で 0.632max に相当する点 $\left(t_{1}, l_{1}\right)$ を原点と直線で結んでその傾きを入り込み速度 $a^{\prime}$ と定義した。

\section{3 光沢部での光沢度の㵊定}

市販の光沢度測定装置（ミノル夕陎製GM-268型）を用いて成形品 の金型光沢部ての光沢度の測定を行った。試料面に対し、規定の入射 角で光束を入射し，正反対方向に反射する光束を受光器て測定する構 造のものて、、鏡面光沢度の基準は黒色ガラスの平滑面としこの場合 の值を100(\%)として表した。今回は 60度鏡面光沢度 Gs（60\%)を用 いた。尚、PP(B301H)については、成形品に透光性があるため光沢度 は正確に剆定できなかった。

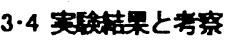

金型の矩形瑇部で、算定した入り込み速度と最終到達値及び最終 空面䅐から、金型の光沢部ては、成形品より測定した光沉度から金型 転写性を評価した。Fig. 5 にその結果を示す。

この結果、Fig. 5 (1)より、最終到達值 向axはテストNNo.3のように 榯脂温度低く、またテストNa. 5、7のように吹き込み速度、吹き 込み圧力が小さいと著しく小さくなることかかかる。一方、その他の 条件ではほとんど maxが最大值の1.05に到達しているためこの罒か らはそれ以上の傾向は確翟てきなかった。また、Fig. 5(2)より、入り 込子速度aに影笕を及ぼす因子は、大きい順に吹き込子速度、吹き込 み压力、金型温度であることかかかる。次に、Fig. 5 (3)より、金型温 度か $90^{\circ} \mathrm{C}$ 以上では 3 墈脂とも最終空面棈(1-Amax)がほぼ0 となる他 はテスト毎の傾向がよく出ており、次の光沢度の図 (Fig. 5 (4))とち ょうど逆の傾向を示している。Fig. 5 (4)よりHDPEと PP(ZS633)とも、 光沉度はテスト№. 10〜12のように金型温度を上げろと一番よく向上 し、次にテスト№４のように吹き込子压力の上昇か効くことかかか ろ。HDPEでは、その他吹き込子速度、榯脂温度を上昇させると光沢度 か向上することか確楒できる。一方、PP(2S633)ては上記の条件以外 でほとんど光沢度の変化は認められなかった。

以上のことから、一般的に、金型温度か高いとそれに接する溶融樹 脂の表面層の温度低下が少ないため 樹脂流動しやすく、樹脂の入 り込みか促進され 高転写か得られると考えられる。また、吹き込子 压力か高い上榯脂シートか機栈的に押されて人り込みか大きくなり、 転写性力狗上すると考えられる。 次に、HDPEにおいて、算定した金型の矩形溝部ての樹脂シートの入り 込子速度、最終到達値及び最終空面積之、金型の光沢部ての成形品の 光沢度を比較し、相関性を調へた。Fig.6にその結果を示す。

Fig. 6 (1)より、自a汃大きくなると光沢度も上昇し相関性は認めら れるが テスト数の大半が 自a最大值の1.05に到達するため それ 以上の傾向は確認できなかった。 Fig. 6 (2)より、入り込み速度aが きくなると光沢度が上昇するという相関性は認められるが 吹き込子 速度の大きいテストについてはこの相関性からは大きく外れている。 この原因は吹き込み速度が速いとそれに比例して入り込み速度も速 
くなるが 入り込み量（最終到達值）は大きくなるまでに至らず、高 転写に結じつかないためと考えられる。それに対して、Fig. 6 (3)最 終空面積と光沢度の関係は、3つのテストで空面稙が0になっても光 沢度が上昇しているためこの領域では傾向は挏めないが 全体的に例 外（特異点）むなく、相関性か鼣められる。
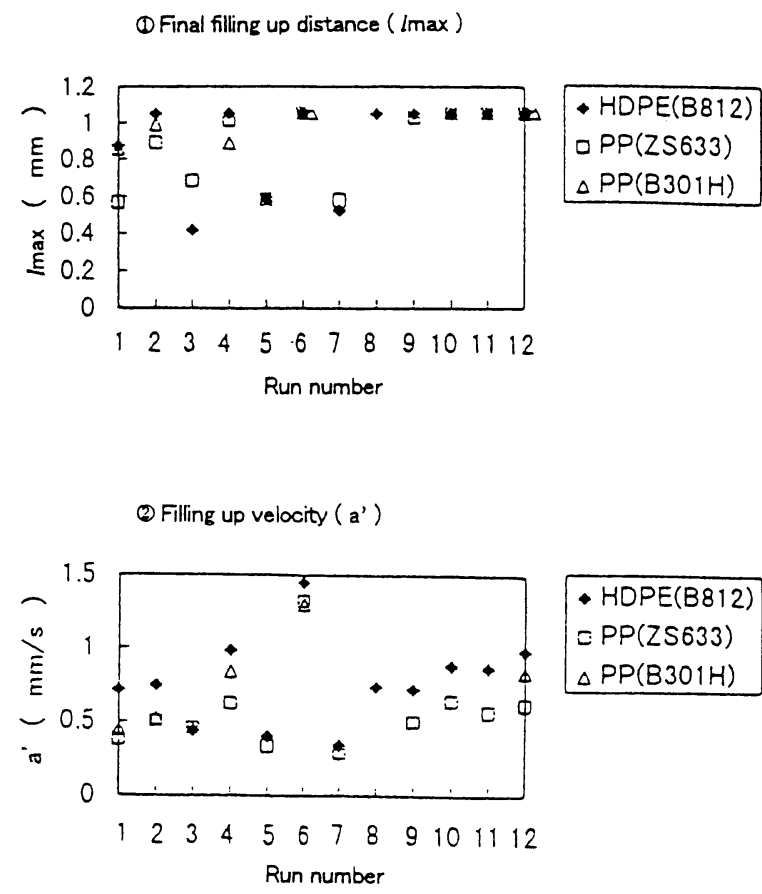

- HOPE(B812)
$=P P(Z S 633)$
$\triangle P P(B 301 H)$

(3) Final vacant area $(1-$ Amax $)$

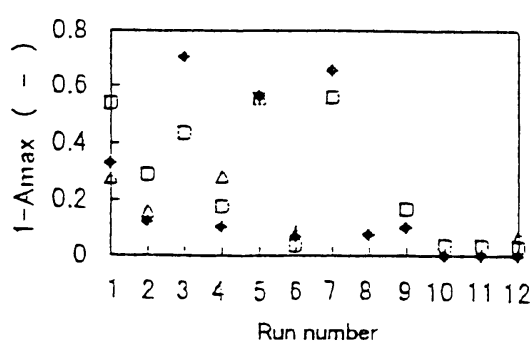

- HDPE(B812)
$\square P P(Z S 633)$
$\triangle P P(B 301 H)$

(4) Gloss

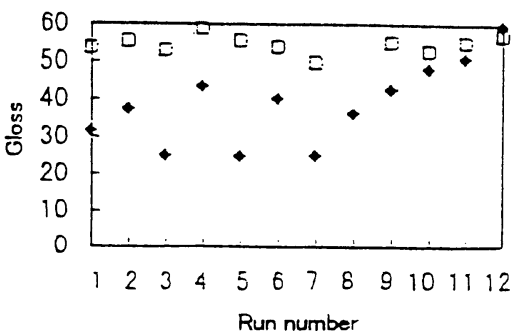

- $\operatorname{HDPE}(B 812)$ $\triangle P P(Z S 633)$

Fig. 5 Evaluation value of mold printabillity for each resin
(1) Final filling up distance ( $I$ max )

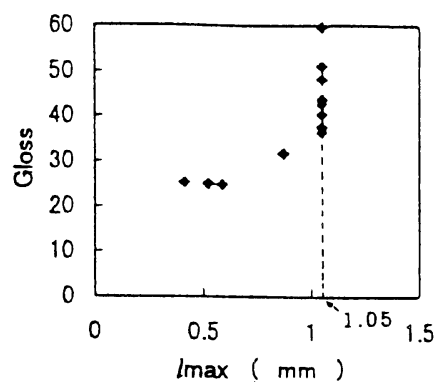

(2) Filling up velocity ( a')

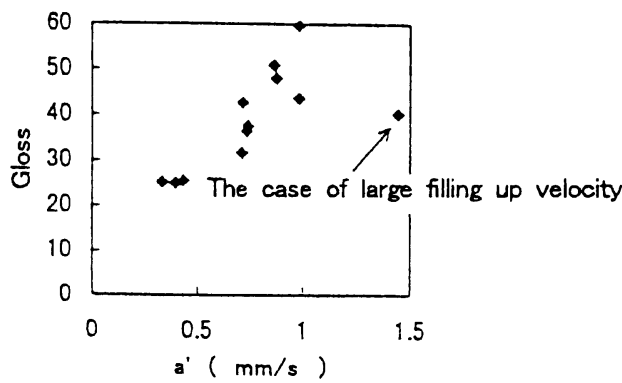

(3) Final vacant area $(1-A \max )$

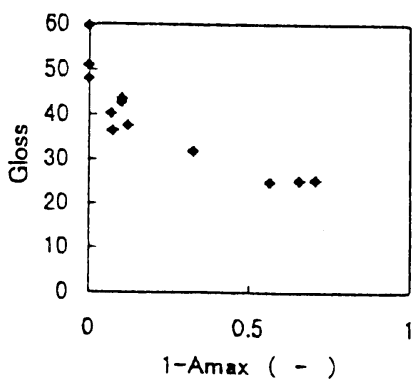

Fig. 6 Correlation of gloss by several parameter for mold printabillity (HDPE)

以上より、光沢度か50以上では最終空面積は0に到達（収束）する という限界はあるが それ以外の領域ては関があり、最終空面積て 転写性（光沢度）か推定でる。従って、転写性の指標でる光沢度

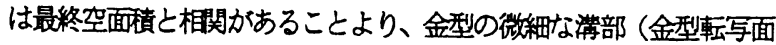
の表面粗度に起因する微細な凹凸）によく充填されることにより高転 写し光沉度が上昇することかかかる。

これらの結果、実祭面の効果としては、例えは、現在、ブロー成形 により多く生産されている自動車のスポイラーは、成形後の表面状態 が悪けため 人の手によりサンティング (サンドペーパーて表面を磨 〈作業)を行っていろが 今回の力法、例えば金型温度を所定の温度 までけゲるとにより、金型転写が良くなることて、サンティングと いう後工程がとんど削減できるため，高級感のある成形品を一工程 
で比較的安価に得ることかできるいう効果があった。また、一方、 例えば新しい楜指の開発において転写性を評価する場合、今回使用し た方法で評価すれば実機マシンて実際に成形せずとも簡単に評価で きるという大きな効果むある。

また、本研究ては、ブロー成形て実際によく成形されている成形品 の表面に加飾されている模様状のものの中で、今まで転写不良か起こ って問題となっていろ筒所の形状、寸法に合わせて、転写の実験を行 っている。しかしながら、今後の課題としては、前述したように、矩 形海部の断面寸法 (瑇幅) を更に小さくして最終到達値が途中て収束 してしまわないような条件て入り込み挙動を探る必要があるという 考えから、試行した結果、瑇幅を0.9mmから0. 5 m程度に替えて行うこ とか望ましい。

尚、流動解析ソフトPOLYFLONを用いて金型の矩形断面满内ての微小 流動の解析を検討中てある。

\section{4. 結 詥}

金型転写のモテルとして、小さい矩形溝部を有する金型を用いて可 視化実験を行い、溶融榯脂の金型内微小流動を観察した結果、以下の 所見か得られた。

(1)転写性の指標である光沢度は入り込み速度及び空面積と相関が あり、特に空面積と相関性か高いことより、金型の微細な䐻部
（金型転写面の表面粗度に起因する微細な凹凸）によく充填さ れることにより高転写し光沢度が上昇すると考えられる。

(2) 金型温度、楜脂温度、吹き込みエア圧力、吹き込みエア流速の 因子か釷型転写性に及ほす影䈏を調へたところ、HDPEとPP （2S633）では、光沉度は金型温度を上げると一番よく向上し 次に吹き込み圧力の上昇力勃くことがかかったまた、HPEで は、その他吹き込子速度、樹指温度を上昇させると光沢度か 向上することか確認された。

\section{貄 辞}

本研究を進めるに当たり，協同て研究いたたいた山口大学工学部応 用化学工学科のMendra Tri S. Ritonga 氏 川崎誠司氏 並ひに御協 カいただいた宇部興産檥研究開発本部の柴田貴章氏に譤を表しま す。

\section{參考文赫}

1）佐野茂彰,プラスチックスエージ, 37, 202(1991).

2) Furuya H, Takatori H, Ferguson L, SPE ANTEC Tech. Papers, 39. 3070(1993).

3）古屋博章，加納好昭，成形加工８８304(1996). 